\title{
Enhancing Teachers' Performance through Training and Development in Ghana Education Service (A Case Study of Ebenezer Senior High School)
}

\author{
Dolores Mensah Hervie $^{1, \text { * }}$, Ernest Christian Winful ${ }^{2}$ \\ ${ }^{1}$ Department of Secretaryship and Management Studies, Accra Technical University, Accra, Ghana \\ ${ }^{2}$ School of Business and Management Studies, Accra Technical University, Accra, Ghana
}

Email address:

dollymensahh@yahoo.com (D. M. Hervie), ephlameswinful@yahoo.com (E. C. Winful)

${ }^{*}$ Corresponding author

\section{To cite this article:}

Dolores Mensah Hervie, Ernest Christian Winful. Enhancing Teachers' Performance through Training and Development in Ghana Education Service (A Case Study of Ebenezer Senior High School). Journal of Human Resource Management. Vol. 6, No. 1, 2018 , pp. 1-8. doi: $10.11648 /$ j.jhrm.20180601.11

Received: December 13, 2017; Accepted: December 27, 2017; Published: January 31, 2018

\begin{abstract}
The aim of this article is to examine training and development of teachers and how it can enhance their performance in delivery under the Ghana Education Service (GES). Performance of teachers is of primary importance to every country and Ghana is not an exception. Teachers are a source of encouragement to their students because of the developed relationship and in addition, provide instructions in their respective academic area. The relatively poor performance of students in recent times has led to this study. The study was based on a case study and quantitative research design. Simple random sampling technique was used to select the respondents (teachers) of the study. A total of 40 questionnaires were distributed out of which 30 representing 75\% were retrieved. The research instrument (teachers' in-service training questionnaire) was designed to have both open and close-ended items. The findings of the study revealed that, poor performance of teachers was due to lack of frequent in-service training, lack of teaching and learning materials, lack of incentives and motivation, and improper supervision. It is therefore, recommended that Ghana Education Service should improve upon its in-service training and development policy to be consistent with the needs of teachers. More so, periodic learning needs assessments should be conducted before training programmes are designed for teachers. Finally, the Teachers' Education Division of Ghana Education Service should be resourced to enable it organize more and regular in-service training programmes for teachers. Finally, teachers should be given the necessary motivation to boost their morale to give off their best performance.
\end{abstract}

Keywords: Performance, Training and Development, In-Service Training, Effective Reward System, Ghana Education Service

\section{Introduction}

Excellent performance of every institution is dependent on its key human resource. Although there are many other factors that play a major role in its success, every educational institution must have quality teachers in order to improve upon the knowledge, skills and general performance of its students. Teacher education, training and development are a means for professional upgrading which deals with all developmental functions directed at the maintenance and enhancement of their professional competence. The quality of teachers that work in a specific educational system help in the attainment of positive learning outcomes in schools. Performance of teachers is partly dependent on their preservice training in addition to the in-service training given to the teachers. Pre-service teacher training programs (PSTP) are very crucial in order to upgrade teachers' skills, knowledge and performance and also to enable them to be more effective. On the other hand, In-service training programs (ISTP) are necessary to re-orientate teachers to new goals and values, to train them in new teaching and learning methods, to prepare them to cope with curriculum change, and to provide them with the knowledge and skills to teach new learning areas (Al-Zoubi et al., 2010). 
Training and development have become the most important factor in the organizational world today, because it increases the efficiency and the effectiveness of both employees and the organization (Raja, Furqan and Khan, 2011). Employee training and development is a major force in the economic success of any institution, and educational institutions cannot afford but to develop the requisite manpower to support both the productive and service industries (Sarbeng, 2013). (Shaheen, Naqvi and Khan 2013) defined training as a systematic development of the knowledge, skills and behaviour required by employees to do adequately on confirmed task or job. According to (Amin et al., 2013) training is simply learning that is provided in order to improve performance on the present job. Employee development is aimed at providing employees with competencies for anticipated future jobs and roles. (Sims, 2002) emphasizes that training focuses on present jobs while development prepares employees for possible future jobs.

Training and development can be thought of as processes designed to enhance the professional knowledge skills and attitudes of educators so that they might, in turn, improve the learning of students. Training and development are important part of teacher preparation programs, especially for those aspects of teaching that are more skilled-like in their conception, but there are many other important aspects of teaching that can only be nurtured through reflective strategies and experiences (Rahman, et al, 2011).

Ebenezer Senior High School is one of the best senior high schools located in the Accra Metropolitan Assembly. Ebenezer Senior High School was started by Robert Aryee some 75 years ago as a primary institution to provide education to the less endowed in his community. Over the years, the school has grown into a second cycle institution giving education to people from all corners of the country. Ebenezer Senior High is well developed under the supervision of Ministry of Education and the Ghana Education Service and has a good capital infrastructure. Rules and regulation for the recruitment of teachers of the School require a person having bachelor degree along with a professional degree of B. Ed. On the other hand In-service training programs of the teachers is largely implemented by the Ghana Education Service under the supervision of the Ministry. However, whether the teachers are given In-service training programs, how regular are the In-service training programs, what kind of In-service training programs, the objective of the In-service training, the method of the Inservice training, and whether the In-service training program enhances the performance of the teachers is not known and has not been assessed over the years.

This study would provide empirical evidence to policy makers - Ghana Education Service (GES) and the Ministry of Education (MOE) on the need to pay special attention to In-service training of teachers, especially those at the Senior High Schools, to assist in raising the decline of the academic performance of the students at the Senior High School. The findings of the study would also provide policy makers the areas the teachers need training to achieve improvement in performance. Finally, the study would help fill the gap on the paucity of research on training and development in the educational sector in Ghana, and also contribute to the body of literature on the effect of training and development on performance in the educational sector.

\section{Statement of the Problem}

Over the years, there has been complaints of a steady decline in the academic performance of students. For instance, statistics released by WAEC in 2015 indicates that $25.29 \%$ of candidates passed in mathematics (A1 to C6, $23.63 \%$ passed in integrated science (A1-C6) and 50.29\% passed in English (A1-C6) (Doozie, 2015). Furthermore, students who sat for the 2016 exams failed in the core subjects of Mathematics, English, Science and Social Studies. About 32 percent of the students obtained the passing grade of A to C6 in the core subjects and 19.82 percent of students obtained D7-E8, which most tertiary institutions consider as a fail score, and about 38.10 percent of students had F9. This has generated much public outcry on the standard of the Ghanaian educational system. Although the blame for the decline can partly be attributed to the lack of educational infrastructure and teacher motivation, much of the problem is due to the lack of regular In-service training for teachers.

In recent years, the Ghana Education Service, through Ministry of Education has shifted focus in providing Inservice training to teachers, especially the Senior High Schools Teacher, to rather providing infrastructure, failing to recognize that this infrastructure is useless without the availability of competent trained teachers to use this educational infrastructure. Hence the main objective of the study was to examine how teachers' performance could be enhanced through training and development thereby improving the overall performance of students.

\section{Literature Review}

Teachers are at the heart of providing quality education to students. They facilitate students' learning and ensure that they thrive academically so that they fulfill their potential and find meaningful careers.

Teachers and the quality of their teaching are now widely recognized as the most critical of many important factors that combine to create overall quality of education (Darling Hammond, 2000; Leu \& Price Rom, 2006; UNESCO, 2004). (Angrist and Lavy, 2001), a study about in-service teachers' training in Jerusalem revealed that there is a significant positive relationship between teachers' training and students' test scores. The cost-benefit analysis of the study also shows that teachers' training could provide a less costly way of improving students' grades than cutting down the class size or increasing the class hours. (Pascal Bressoux et al December, 2008), the way a teacher delivers knowledge/lecture is not changed by the training he/she receives. The improvement in students' performance with a trained teacher is just because of 
a better grip on subject matter.

Training of teachers' is also necessary especially in today's environment to cope with the changing demands of the profession. Trained teachers' are in a better position to educate the students. Training could improve a teacher's knowledge on subject matter, teaching method etc.

However, teachers' in many developing countries have little or no preservice preparation before starting to teach and may not have opportunities to participate in in-service professional development activities.

The goal of in-service professional development is to improve the knowledge, skills, and commitments of teachers' so that they are more effective in planning lessons, using variety of effective approaches in their teaching, and monitoring students' learning as well as in undertaking other school and community responsibilities.

Good teaching may be defined as instruction that leads to effective learning, which in turn means thorough and lasting acquisition of the knowledge, skills, and values the instructor or the institution has set out to impart. The education literature presents a variety of good teaching strategies and research studies that validate them (Campbell and Smith 1997; Johnson et al. 1998; McKeachie 1999). The research has shown that teacher quality is an important factor in determining improvement in students, even after accounting for prior student learning and family background characteristics. Considering the purpose of this article the following strategies would help evaluate how they impact on the academic performance of students.

\subsection{Pedagogy, Andragogy and Teacher Performance}

Pedagogical approaches are often placed on a spectrum from teacher-centered to learner-centered pedagogy. Teachercentered pedagogy positions where the teacher is at the center of the learning process and typically relies on methods such as whole-class lecture. The teacher assumes responsibility for making decisions about what would be learned, how it would be learned, when it would be learned, and why it is of value to the learner. Pedagogy refers to the interactions between teachers, students, and the learning environment and the learning tasks. This broad term includes how teachers and students relate together as well as the instructional approaches implemented in the classroom.

A learner-centered approach to instruction where the teacher acts as a facilitator to help bridge the gap between student and knowledge. The learner is viewed as an independent entity who enters the learning experience with a unique set of experiences and motivators. This pedagogical approach generally draws on learning theories where learners play an active role in the learning process. Students therefore use prior knowledge and new experiences to create knowledge. The teacher facilitates this process, but also creates and structures the conditions for learning.

Malcolm Knowles, often referred to as the Father of Adult Education, described andragogical approaches as one where the teacher is a facilitator who aids adults to become selfdirected learners, in The Journal of Technology Studies, according to a 2000 article by Dr. Geraldine (Gerri) Holmes and Michele Abington-Cooper.

The task of an instructor is to remove barriers to learning such as, fears or misapprehensions and to open up opportunities for acceptance of new knowledge, skills, or abilities.

Research suggests that andragogical approaches help to motivate adult learners to create new skills and link information with experience, which results in increased knowledge retention.

Pedagogical approaches assume that the experience with the instructor is the most valuable means to acquiring knowledge. Learners enter the classroom with little or no knowledge, and the means to attain knowledge is held by the instructor. Thus, the instructor must be the main point of focus in the learning experience for results to be achieved, according to (Mark K. Smith, 2002) Pedagogical effectiveness often depends on ensuring that the approach is appropriate for specific school and national contexts.

\subsection{In-Service Training and Teacher Performance}

In-service training program for teachers tends to increase the qualities possessed by a good teacher which positively affect the performance of a teacher. (Harris and Sass, 2001) studied effects of teacher training on teacher value added. The result showed that training of a teacher was positively associated with productivity in middle and high school math. The results further revealed that more experienced teachers appeared more effective in teaching elementary and middle school reading.

In the modern world, in-service training plays a crucial and pivotal role in improvement of education. To meet the institutional needs in term of skills and knowledge, the roles and capabilities of trainees can be improved through in-service training. Only trained teachers can set goals for teaching and can organize plans for reaching those goals (Pintrich \& Schunk, 2002). Effective teachers have good strategies for helping students (Bockerts, Pitrich \& Zeidner, 2000).

Training works as a catalyst which provokes a significant change in a teacher, redefines role, broadens vision and enhances the attributes of a teacher. In-service teacher training enables teachers to be more systematic and logical in their teaching style (Kazmi, Pervez, Mumtaz, 2011).

\subsection{Educational Infrastructure and Teacher Performance}

Improving the quality of school facilities is an expensive undertaken. However, when the positive impacts of facility improvement on teachers and students are translated into dollar figures, the rewards far outstrip the cost of investments. There are five primary facets of school facilities: noise, air quality, lighting, temperature, and space. The quality of school infrastructure has a significant effect on school attendance and drop-out rates. Students are less likely to attend schools in need of structural repair, schools that use temporary structures, and schools that have understaffed janitorial services (Branham D, 2004). According to (Earthman, G. I., \& Lemasters, L. K. 2009) Teachers in 
schools with satisfactory conditions are significantly more likely to express positive attitudes about their classrooms than teachers in unsatisfactory buildings (across a wide range of indicators, but limited sample prevents causal inferences).

The condition of school facilities has a measurable effect over and above socioeconomic conditions on student achievement and teacher experience/turnover. Additionally, at least $75 \%$ of principals indicated that the adequacy of the school facility impacted teacher attitudes, teacher recruitment and retention, student behavior, and parent and community attitudes and support.

\subsection{Rewards and Teacher Performance}

(Asare-Bediako, 2013) states that employees provide performance while organizations offer rewards. Reward system are designed not only to motivate but also to maintain desired behavior and performance. A properly administered rewards system has the capacity to improve incentives for quality workmanship and teaching performance as well as strategically attracting skilled workers to join an institution whereas the reverse may lead to unproductive performance and even to a high incidence of teacher turnover (Wilson, 2004). Effectively maintained reward system creates a motivating environment that may enhance performance. (Oluremi, 2013) making the salary and compensation of teachers very attractive would enhance teachers' performance. Thus educational infrastructure, in-service training and good rewards mutually have a positive influence on the performance of teachers which may in a long run improve the performance of students.

\section{Methodology}

This research was based on a case study and quantitative research design. Simple random sampling technique was used to select the respondents (teachers) of the study. A total of 40 teachers were sampled for the study out of which 30 teachers representing $75 \%$ responded to the study by answering and returning the questionnaire. The research instrument (teachers' in-service training questionnaire) was designed to have both open and close-ended items by the researcher. Pilot administration of the instruments to inservice teachers at Ebenezer Senior High School enabled reliability tests to be carried out. Close-ended items were analyzed and various statistics (Frequency and percentages) were quantitatively derived. Responses to the open-ended items were summarized as observed and quantitatively analyzed as close-ended items.

\section{Results and Discussions}

Table 1 shows the summary of the background of the respondents. Majority (73.3\%) of the respondents were found to be 40 years and above, while $26.7 \%$ were found to be in the age group of 20 to 39 years. This implies that the teachers were of age and as a result, training and development of teachers should be focused more on the younger ones who have the potential to work for long period of time to achieve improvement in the academic performance of the teachers. The older ones should also be given in-service training from time to time to refresh their teaching skills and other areas of concern to their delivery, more attention should be paid to the younger ones who are new in the teaching profession, since such ones may be willing to put into practice training given to them to achieve desired results than the older ones.

The gender of the respondents indicates that majority $(63.3 \%)$ of them were males while $36.7 \%$ of them were females. This finding shows a gender disparity issues in the human resource base of the institution. Notwithstanding this gender issues, inservice training of teachers should be equitable and fair to ensure that female teachers are not left behind. On the other hand, $70.0 \%$ of the respondents were found to be married, $26.7 \%$ were single, and 3.3\% had lost their partners in death. This finding underscores the need to focus attention on the single teachers who are more focused on their job and can do more (Single parents and those who had lost their partners in death should be encouraged not to get more distracted with other issues apart from their core mandate of teaching).

The education level of respondents examined indicated that $73.3 \%$ of the respondents were degree holders, while $26.7 \%$ were second degree holders. On the other hand, in terms of professional qualification of the respondents, $63.0 \%$ had a 3 year Cert A, 22.2\% had Specialized training, and $14.8 \%$ had Bachelor of Education. This finding reveals that there is a well-qualified teacher population at the senior high school. This should have a positive impact on the academic performance of the students. On the contrary, this is not the case as the national data on the WASSCE results indicates a decline in the performance of the students. This underscores the need for regular in-service training for the teachers.

Table 1. Background Information of Respondents.

\begin{tabular}{lll}
\hline Background Information & N & \% \\
\hline Age of respondents & & \\
20-29 years & 3 & $10.0 \%$ \\
30-39 years & 5 & $16.7 \%$ \\
$40-49$ years & 13 & $43.3 \%$ \\
50 years and above & 9 & $30.0 \%$ \\
Sex of Respondents & & \\
Male & 19 & $63.3 \%$ \\
Female & 11 & $36.7 \%$ \\
Marital status of respondents & & \\
Married & 21 & $70.0 \%$ \\
Single & 8 & $26.7 \%$ \\
Widowed & 1 & $3.3 \%$ \\
Educational level of respondents & & \\
Degree Holder & 22 & $73.3 \%$ \\
Second Degree Holder & 8 & $26.7 \%$ \\
Professional qualification of respondents & & \\
Cert A 3 years & 17 & $63.0 \%$ \\
Specialized training & 6 & $22.2 \%$ \\
Bachelor of Education & 4 & $14.8 \%$ \\
Length of service of respondents & & $13 \%$ \\
1-5 years & 4 & $13.3 \%$ \\
6-10 years & 4 & $20.0 \%$ \\
11-15 years & 6 & $16.7 \%$ \\
16-20 years & 8 & \\
21-25 years & 5 & \\
26 years and above & & \\
\hline & & \\
\hline
\end{tabular}


The length of service of the respondents revealed that $26.6 \%$ of the teachers had 1-10 years teaching experience, $46.7 \%$ had $11-20$ years teaching experience, while $26.7 \%$ had more than 20 years teaching experience. This finding shows that the respondents are well experienced, hence understands the impact training and development have on the performance of teachers and their implication on the academic performance of the students.

\subsection{In-Service Training Practices}

To investigate the in-service training practices at the Ebenezer Senior High School, the respondents were asked to indicate whether they have ever attended in-service training apart from their pre-service training, and how many times they have attended in-service training. Figures 1 and 2 present the results on the in-service training attendance, and the number of in-service training attended by the respondents.

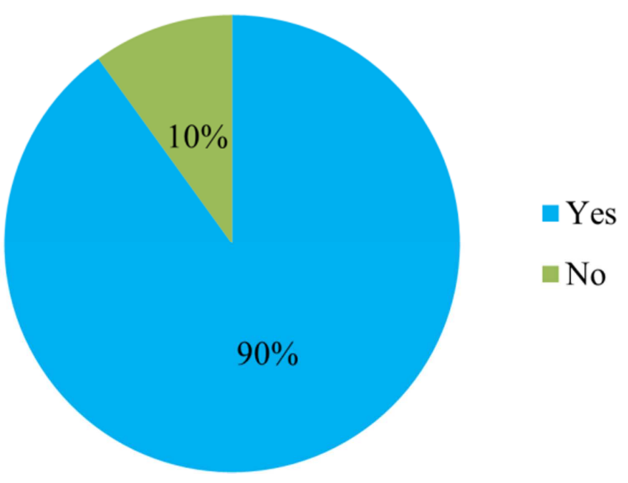

Figure 1. In-service training attendance.

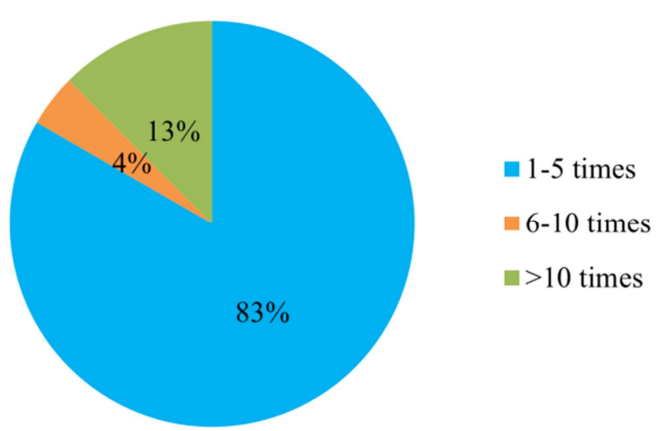

Figure 2. Number of in-service training.

Figure 1 shows that majority $(90.0 \%)$ of the teachers attended in-service training, while $10.0 \%$ had never attended any in-service training since their pre-service training. Although the proportion of teachers who never attended inservice training were less compared to those who attended, the number is still significant due to the fact that in-service training is the training given to both novices and the more experienced ones in the profession to improve their role effectiveness. It is therefore expected that all the teachers at the school should at this time had attended an in-service training course. This shows that the Ghana Education Service was not given all the proper and needed attention to the inservice training of the teachers. This fact is corroborated by the results in Figure 2, as majority $(83.0 \%)$ of the teachers reported of attending in-service training not more than five times, with only $17.0 \%$ of the teachers attending in-service training more than five times.

\subsection{Type, Method and Objective of the In-Service Training Programs}

The respondents were asked about the type, method and the objective of the in-service training program they had attended. This was to determine the type, method and the objective of the in-service training programs of the teachers. Tables 1, 2 and 3 present the summary of the results. As shown in Table 1, the teachers were given in-service training in the form of specialized in-service training (88.9\%), teachers' study guide $(14.8 \%)$, and through promotion courses. This finding shows that the in-service training given to the teachers by the Ghana Education Service was mostly based on specialties rather than general in-service training. According to (Ngala \& Odebero, 2010), such teachers' development programs impacted on teachers' effectiveness if they enable teachers to master relevant content areas on which national examinations are based.

Table 2. Type of training courses.

\begin{tabular}{|c|c|c|c|}
\hline \multirow[b]{2}{*}{ Training courses } & \multicolumn{2}{|c|}{ Responses } & \multirow{2}{*}{$\begin{array}{l}\text { Percent of } \\
\text { Cases }\end{array}$} \\
\hline & $\mathbf{N}$ & Percent & \\
\hline Specialized in-service training & 24 & $72.7 \%$ & $88.9 \%$ \\
\hline Teachers' study guide & 4 & $12.1 \%$ & $14.8 \%$ \\
\hline Promotion courses & 5 & $15.2 \%$ & $18.5 \%$ \\
\hline Total & 33 & $100.0 \%$ & $122.2 \%$ \\
\hline
\end{tabular}

Table 3. Objective of training courses.

\begin{tabular}{llll}
\hline & \multicolumn{2}{c}{ Responses } & $\begin{array}{l}\text { Percent of } \\
\text { Cases }\end{array}$ \\
\cline { 2 - 3 } & $\mathbf{N}$ & Percent & \\
\hline To learn about new syllabus & 6 & $18.2 \%$ & $25.0 \%$ \\
To prepare teaching/learning aids & 8 & $24.2 \%$ & $33.3 \%$ \\
To learn about new methods & 19 & $57.6 \%$ & $79.2 \%$ \\
Total & 33 & $100.0 \%$ & $137.5 \%$ \\
\hline
\end{tabular}

Table 3 shows that the in-service courses given to the teachers dealt with specific themes related to teaching; teaching methods $(79.2 \%)$, preparing teaching and learning aids $(33.3 \%)$, and learning about new syllabus $(25.0 \%)$. According to (Atsenga, 2002) such training areas impacts positively on learning and that teacher development programs, which promote knowledge on choice and use of effective teaching methods, impacted on teachers' role effectiveness. It has also been found that for effective learning to take place, choice of appropriate teaching methods must be made depending on the topics. On the other hand, knowledge of school management, instructional leadership, evaluation techniques, teaching as a profession, mastery of subject matter, and guidance and counseling had also been found to impact on academic achievement (Ngala \& Odebero, 2010). On this note, in-service training of teachers should also focus on these areas to help raise the falling standard of education. 
Table 4. Methods used in in-service training.

\begin{tabular}{lllll}
\hline Training Methods & & Frequency & Percent & Valid Percent \\
\hline Valid & Pedagogy & 21 & 70.0 & 80.8 \\
& Andragogy & 5 & 16.7 & 19.2 \\
Missing & Total & 26 & 86.7 & 100.0 \\
Total & No Response & 4 & 13.3 & 100.0 \\
\hline
\end{tabular}

The methods used to train teachers had a profound impact on the acquisition of knowledge by the students. Teachers therefore need to be taught using andragogical approach so that they would be able to apply such concepts in the classroom. Each student in the classroom has different intelligent levels and as a result teachers should regularly be given in-service training on how to apply different teaching methods to assist average students in the classroom. Table 4 shows that the teachers are mostly given in-service training through Pedagogy (child learning) - $80.8 \%$ as compared to Andragogy (adult learning) - 19.2\%. This may have contributed to the decline in the WASSCE results, since a balanced of both learning methods may enhance teaching and learning in the classroom.

\subsection{Effectiveness of In-Service Training Programs}

The teachers were asked about the effectiveness of the inservice training programs they had attended. This was to determine the effectiveness of in-service training in improving the performance of teachers. The results are discussed as follows:

Table 5. In-service training in enhancing capacity of teachers.

\begin{tabular}{lllll}
\hline & Frequency & Percent & $\begin{array}{l}\text { Valid } \\
\text { Percent }\end{array}$ & $\begin{array}{l}\text { Cumulative } \\
\text { Percent }\end{array}$ \\
\hline Strongly Agree & 25 & 83.3 & 83.3 & 83.3 \\
Agree & 5 & 16.7 & 16.7 & 100.0 \\
Total & 30 & 100.0 & 100.0 & \\
\hline
\end{tabular}

According to Table 5 the teachers reported that in-service training enhances their capacity to improve their performance in the classroom. Majority $(83.3 \%)$ of the teachers strongly agreed that the in-service training they attended had enhanced their capacity to improve their performance in the classroom, while $16.7 \%$ agreed that the in-service trainings they attended had enhanced their capacity which has improved their performance. This finding is consistent with the findings of (Oluremi, 2013). According to the author, in the area of self-development capacity building, training and retraining of teachers are linked to teacher's performance.

Table 6. In-service training in enhancing productivity.

\begin{tabular}{lllll}
\hline & Frequency & Percent & Valid Percent & $\begin{array}{l}\text { Cumulative } \\
\text { Percent }\end{array}$ \\
\hline Strongly Agree & 22 & 73.3 & 73.3 & 73.3 \\
Agree & 8 & 26.7 & 26.7 & 100.0 \\
Total & 30 & 100.0 & 100.0 & \\
\hline
\end{tabular}

The teachers also reported that the in-service training they attended has increased their level of productivity and development. More than $70.0 \%$ of the teachers strongly agreed that in-service training has increased their level of productivity and development, while $26.7 \%$ agreed that inservice training has increased their level of productivity and development. This result gives the indication that regular inservice training of teachers helps them to be more competent by building their capacity and also improves their level of productivity and development. This finding is consistent with the findings of (Issahaku, Ahmed \& Bewa-Erinibe, 2014), who found that training and development leads to improvement in the performance of employee. The finding is also consistent with that of (Pilbean and Corbrige, 2006) who found that effective in-service training is geared towards enhancing quality, reducing cost and improving performance.

\subsection{Factors That Improve Performance of Teachers}

The researcher identified a significant relationship between training and development, and performance of teachers. The variables: regular in-service training, effective reward system and motivation, provision of proper and relevant teaching aids are linked to teachers' performance.

These are in line with many studies on performance of employees which indicated a strong association between teacher motivation and improvement in performance. (Oluremi, 2013) found a significant relationship between teacher motivation and teacher job performance competency.

The research further emphasize that teaching and learning materials are essential and significant tools needed for teaching and learning of school subjects to promote teachers 'efficiency and improve students' performance. According to (UNESCO, 2008), teaching and learning materials such as textbooks, classrooms, teaching aids (chalk, board, ruler and protractor), stationeries and laboratories affect positively academic performance of the learners. (Mutai, 2006) also asserted that learning is strengthened when there is enough reference materials such as textbooks, exercise books, teaching aids and classrooms which directly have a positive impact on academic achievement.

Provision of adequate infrastructure was reported by the teachers to have an impact on their performance and in the long-run on the academic achievement of teachers. Writing on the role of adequate infrastructure on performance in teaching, (Balogun, 2002) submitted that no effective education programme could exist without equipment for teacher. Thus, training and development has a strong relationship with teacher job performance based competencies.

The results analyzed above are confirmed by the Chi-square Goodness-of-Fit test. The result of the test is shown in Table 7. 
Table 7. Chi-square Goodness-of-Fit Test on In-service training in enhancing Performance of teachers.

\begin{tabular}{ll}
\hline & Performance \\
\hline Chi-Square & $21.800^{\mathrm{a}}$ \\
df & 2 \\
Asymp. Sig. & 0.000 \\
\hline
\end{tabular}

The Chi-Square Test of Goodness-of-Fit performed to determine whether the views of the teachers on in-service training programs in enhancing performance of teachers were different from expected revealed that the views of the teachers on in-service training programs in enhancing performance of teachers are not different from expected $\chi^{2}(2, N=30)=21.8, p<.05$. Thus, the null hypothesis is rejected.

\section{Conclusion}

The study concluded that training and development formed an integral part of human resource management for every institution and there is a strong relationship between teachers' performance and poor performance of students. To solve the problem of the decline in the performance of students at WASSCE and to raise the standard of education in Ghana, teachers' performance needs to be enhanced. The Ghana Education Service must invest more into the inservice training of the teachers. The study found out that inservice training was not organized regularly (more than 2 years intervals) and those held centered on learning aids, new syllabus, and new methods of teaching. It further came to light that teacher motivation was very minimal enough to increase the morale of teachers in order to enhance their performance. It was found that in-service training programs were significant in enhancing performance of teachers.

\section{Recommendations}

In the light of the results of the study, the researcher recommends that Ghana Education Service (GES) should develop a training and development policy that would regularize the frequent organization of in-service training aiming at enhancing the performance of teachers and improving their educational proficiency in order to help them acquire the skills and the knowledge plus keeping them informed about the latest developments in the educational field. More of andragogical approach should be used for Inservice training and it should be competency based to make trainings more practical. Introduction to internet media, new informatory literature could also bring innovation to teaching methodology. Teachers' education division of the Ghana Education Service should be resourced to carry out training needs assessment before trainings are designed. Conditions of service of teachers should be made attractive to motivate them to give off their best. Provision of adequate infrastructure improved work environment, availability of logistics, attractive salaries, human resource management policies and other requisites may also help in building quality education and teacher retention. However, these conditions need medium to long term approaches.

\section{References}

[1] Al-Zoubi, S., Bani, A. R. M., Ismail, H. (2010). The Effect of in-Service Training Program in Improving Performance Competencies for Learning Disabilities Resource Room Teachers in Jordan. Educators Digest, 10: 4-11.

[2] Amin, A., Rashid-Saeed, M., \& Lodhi, R. N. (2013). The Impact of Employees Training On the Job Performance in Education Sector of Pakistan. Middle-East Journal of Scientific Research, 17 (9), 1273-1278.

[3] Ankomah, Y. A. (2002). The Success Story of Private Schools in Ghana: The Case of Three Schools in Cape Coast. Journal of Educational Management, 4, 1-14.

[4] Atsenga, M. (2002). Factors affecting the teaching of oral communication in English language in secondary schools of Kakamega and Vihiga districts of Kenya. Unpublished M. Ed Thesis, Egerton University, Njoro.

[5] Balogun, T. A. (2002). Improvisation of Science Teaching Equipment. Journal of the Science Teachers Association, 20 (2), $72-76$.

[6] Bockerts, M., Pitrich, P., \& Zeidner, M. (2000). Handbook of self-regulation. San Diego: Academic press.

[7] Campbell, W. E., and K. A. Smith (Eds.). 1997. New paradigms for college teaching. Edina, MN: Interaction Book Company.

[8] Darling-Hammond, L. (2000). How teacher education matters. Journal of Teacher Education, 51 (3), 166-173.

[9] Davis, S., \& Davis, B. (1998). Effective training strategies. San Francisco: Barrett-Koehler Publishers.

[10] Earthman, G. I., \& Lemasters, L. K. (2009). Teacher attitudes about classroom conditions. Journal of Educational Administration, 47 (3), 323-335.

[11] Farquhar, S. E. (2003). Quality Teaching Early Foundations: Best Evidence Synthesis. New Zealand Ministry of Education.

[12] Harris, D., \& Sass, T. (2001). The Effects of Teacher Training on Teacher Value Added Journal of Teacher Education, 51, 164-169.

[13] Heng, M., \& Tam, K. (2006). Special education in general teacher education programs in Singapore. Teacher Education and Special Education, 29, 149-156.

[14] Issahaku, A., Ahmed, D., \& Bewa-Erinibe, P. L. (2014). Enhancing Employee Performance through Training: The Case of Tamale Teaching Hospital in Ghana. European Journal of Business and Management, Vol. 6, No. 29.

[15] Koch, S. (2007). Training rural special educators online to teach social skills. Aural Special Education Quarterly, 26, 16-20.

[16] Kwadwo Asare-Bediako (2013), Professional skills in Human Resource Management, Third Edition. Ghana.

[17] Moyles, J., Adams, S. \& Musgrove, A. (2002). Brief No: RB363, Study of Pedagogical Effectiveness in Early Learning. Anglia Polytechnic University. 
[18] Mutai, B. K. (2006). How to write quality research proposal: a complete and simplified recipe. New York: Talley Publications.

[19] Ngala, B. J. A. F. \& Odebero, S. O. (2010). Teachers' perceptions of staff development programmes as it relates to teachers' effectiveness: A study of rural primary schools in Kenya. Educational Research and Review, Vol. 5 (1), pp. 001-009.

[20] Oluremi, O. F. (2013). Improving teacher performance competency through effective human resource practices in Ekiti State secondary schools. Singaporean Journal of Business Economics, and Management Studies, Vol. 1, No. 11.

[21] Pilbeam, S. \& Carbridge, M. (2006). People Resourcing: Contemporary HRM in Practice. Third Edition.

[22] Pintrich, P., \& Schunk, D. (2002). Motivation in education: Theory, research, and applications (2nd ed.). Englewood Cliffs, NJ: Prentice Hall.

[23] Rahman, M. S. B. A. \& Al-Zoubi, S. M. (2011). The Effects of a Training Program in Improving Instructional Competencies for Special Education Teachers in Jordan. Educational Research, Vol. 2 (3) pp. 1021-1030.

[24] Raja, A. G., Furqan, A. K., Khan, M. A. (2011). Impact of Training and Development on Organizational Performance. Global Journal of Management and Business Research, Volume 11, Issue 7.

[25] Sarbeng, I. A. (2013). Staff Training and Development
Interventions and Teaching Performance: Application of Structural Equation Modeling. International Journal of Human Resource Studies, Vol. 3, No. 4.

[26] Shaheen, A., Naqvi, S. M. H. \& Khan, M. A. (2013). Employees Training and Organizational Performance: Mediation by Employees Performance. Interdisciplinary Journal of Contemporary Research in Business, Vol 5, No. 4.

[27] Sheets, M. E. (2009). The relationship between the condition of school facilities and certain educational outcomes, particularly in rural public high schools in Texas. (Ed. D. Texas. Tech University.)

[28] Sims, R. (2002). Organizational Success through Effective Human Resources Management. Westport CT: Quorum Books.

[29] Smith, M. K. (2015). What is education? A definition and discussion. The encyclopedia of informal education.

[30] Stevenson, K. R. (2001). The relationship of school facilities conditions to selected student academic outcomes: A study of South Carolina public school s. SC Education Oversight Committee.

[31] UNESCO. (2004). EFA global monitoring report 2005: The quality imperative. Paris: Author.

[32] UNESCO (2008). Challenges of implementing free day secondary education in Kenya. Experiences from district. UNESCO, Nairobi. 